\title{
New bioactive peptide reduces the toxicity of chemotherapy drugs and increases drug sensitivity
}

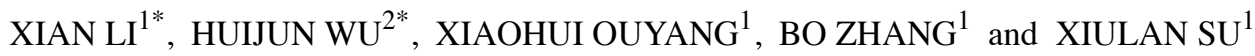 \\ ${ }^{1}$ Clinical Medical Research Center, The Affiliated Hospital, Inner Mongolia Medical University, \\ Hohhot, Inner Mongolia 010050; ${ }^{2}$ Department of Hepatobiliary Pancreatic Surgery, \\ Inner Mongolia People's Hospital, Hohhot, Inner Mongolia 010010, P.R. China
}

Received March 24, 2016; Accepted July 4, 2016

DOI: $10.3892 /$ or.2017.5674

\begin{abstract}
Anticancer bioactive peptide (ACBP) is extracted from normal goat spleens and exhibits antitumor activity alone and in combination with low cisplatin doses to achieve antitumor efficacy similar to higher cisplatin doses via sustained medication modes. In the present study, we investigated whether elevated levels of induced or normal ACBP in MKN-45 gastric cancer (GC) cells may reduce their toxicity to oxaliplatin (L-OHP) in a dose-dependent manner. The growth inhibition rate (IR), morphological changes and gene expression were examined in MKN-45 GC cells. Compared with normal ACBP, induced ACBP alone significantly enhanced the anticancer activity of L-OHP-mediated apoptosis and reduced the amount and side-effects of L-OHP $(\mathrm{P}<0.05)$. The inhibition of cancer cell growth at high concentrations of induced ACBP and L-OHP was significantly more effective than at low concentrations. In addition, for the first time, we examined the potential of a combination of induced ACBP and L-OHP to increase L-OHP sensitivity in human gastric carcinoma xenograft tumors. Nude mice were implanted with human gastric carcinoma MKN-45 cells and treated with an intraperitoneal injection of $0.5 \mathrm{ml}$ of normal saline, $30 \mu \mathrm{g} / \mathrm{ml}$ ACBP, $20 \mu \mathrm{g} / \mathrm{ml}$ $\mathrm{L}-\mathrm{OHP}$ or $30 \mu \mathrm{g} / \mathrm{ml} \mathrm{ACBP}+20 \mu \mathrm{g} / \mathrm{ml} \mathrm{L-OHP}$ [combination of anticancer bioactive peptide and oxaliplatin $(\mathrm{A}+\mathrm{L})]$ via the tail vein twice a week. In vivo short-term intermittent use of induced ACBP alone significantly inhibited MKN-45 tumor
\end{abstract}

Correspondence to: Professor Xiulan Su, Clinical Medicine Research Center, The Affiliated Hospital, Inner Mongolia Medical University, 1 Tongdao North Street, Hohhot, Inner Mongolia 010050, P.R. China

E-mail:xlsu@hotmail.com

*Contributed equally

Abbreviations: ACBP, anticancer bioactive peptide; L-OHP, oxaliplatin; NS, normal saline; $\mathrm{A}+\mathrm{L}$, combination of anticancer bioactive peptide and oxaliplatin

Key words: anticancer peptide activity, oxaliplatin, gastric cancer, nude mouse xenograft growth. The combination of induced ACBP and L-OHP also significantly improved the quality of life of the nude mice and reduced the toxicity of L-OHP. Based on flow cytometry and gene expression analyses, $\mathrm{A}+\mathrm{L}$ significantly increased the proportion of cells in the $\mathrm{G} 2 / \mathrm{M}$ phase $(\mathrm{P}<0.05)$ relative to ACBP or L-OHP alone, and short-term intraperitoneal injection of ACBP increased the sensitizing effect of L-OHP. Collectively, these results suggest that high levels of induced ACBP in combination with L-OHP via a short-term intermittent medication mode could be a useful clinical therapeutic strategy for GC.

\section{Introduction}

Currently, quality of life is one of several important indicators used to evaluate the efficacy of treatment; it is not only based on clinical objective indices as evaluation standards but also emphasizes the subjective conditions of cancer patients (1). The incidence of gastric cancer (GC) has decreased in the past decade, but it remains the leading cause of cancer-related mortality in China $(2,3)$. Despite recent developments, surgery, chemotherapy and radiotherapy are not effective in completely eradicating GC cells $(4,5)$. Systemic chemotherapy is widely accepted as a palliative treatment, leading to good responses, improved life quality, and increased survival rates. Palliative treatment is designed to relieve the symptoms and improve quality of life. Today, a great challenge of cancer chemotherapy is to eliminate cancer cells and improve the quality of life of patients.

Chemotherapy has been vigorously investigated in GC, but single-drug chemotherapy has not increased the survival rates. However, several combination treatments have been established with potent anticancer activity. For example, oxaliplatin + cisplatin (L-OHP/CDDP) combination therapy is frequently used for the pre-treatment of ovarian cancer (6). GEM (gemcitabine) is used in combination with 5-fluorouracil (5-FU)/oxaliplatin (L-OHP) for the treatment of advanced pancreatic cancer (7). This therapy improves the quality of survival, prolongs the survival time, and shows lower toxicity. Hydroxycamptothecin (HCPT) has been used in combination with 5-FU/mitomycin C (MMC) for the treatment of advanced pancreatic cancer (8). Rebucci and Michiels observed several common drug resistance mechanisms in GC, 
including failure of DNA repair or apoptosis, changes in drug export and in drug metabolism (9). Although combination treatments are encouraging, high (and non-specific) toxicity and drug resistance discourage the continuation of treatment. Therefore, great effort has been directed toward enhancing drug specificity, reducing toxic side-effects, and preventing drug resistance. Development of novel therapeutic anticancer agents is important $(10,11)$, especially agents without the non-specific toxicity of current drugs. L-OHP, a third-generation platinum compound, after cisplatin and carboplatin, is used to treat digestive system tumors with high clinical activity and low mammalian toxicity. L-OHP is a new 1,2-diaminocyclohexane (DACH) platinum complex with antitumor activity similar to that of cisplatin against several transplanted murine tumors (12). L-OHP differs from cisplatin and carboplatin, particularly in its toxicity profile due to the absence of renal and auditory toxicities and minimal myelosuppression (13). However, L-OHP is toxic to the blood and nervous system, which inhibits its broader application for cancer therapy (14).

Induced anticancer bioactive peptide (ACBP) is a low-molecular-weight active substance extracted from goat spleen via induced immunity and was produced by the Clinical Medicine Research Center, The Affiliated Hospital at Inner Mongolia Medical University. While normal ACBPs are also extracted from goat spleen, they are not induced during the immunity process. Normal and/or induced ACBPs show superior antineoplastic activity and a lack of toxicity and side-effects (15). In culture, ACBPs were found to inhibit tumor growth in nude mice bearing Dutch gallbladder carcinoma GBS-SD, Dutch GC BGS-823, and GC MGS-803 cells via a sustained medication mode every few days $(15,16)$. Previously, we demonstrated that ACBP combined with lower cisplatin doses could achieve antitumor efficacy similar to the efficacy of higher doses of cisplatin alone via a sustained medication mode (17). However, the potential antitumor efficacy of short-term intermittent ACBP (induced or normal) medication modes and the combination with chemotherapeutics has not been previously demonstrated.

Here, we investigated the anticancer effects of short-term intermittent application of ACBPs (induced or normal) in combination with L-OHP in a dose-dependent manner in MKN-45 GC cells. We also investigated the antitumor efficacy of induced ACBP treatment together with L-OHP using discontinuous short-term applications by examining cell apoptosis signaling in vitro and whether combined treatment of induced ACBP and L-OHP could enhance tumor regression in a mouse xenograft model in vivo, improve the qualities of life of nude mice with MKN-45 cell Dutch GC xenografts and cause overexpression of cytochrome $c$, caspase-3, -8, and -9 in the tumor cells. We found that induced ACBP enhanced L-OHP-stimulated apoptosis, reduced the toxic side-effects of L-OHP, and inhibited tumor cell growth. These results provide novel ideas and strategies for comprehensive tumor treatment in the future.

\section{Materials and methods}

Materials. ACBP and MKN-45 cells were provided by the Clinical Medicine Research Center, The Affiliated Hospital, Inner Mongolia Medical University. L-OHP was produced by Jiangsu Aosaikang Pharmaceutical Co., Ltd. by Share Ltd. (Chinese Medicine, license no. H20064296).

MTT assay for cell viability evaluation. Cell viability was evaluated after treatment with an MTT assay. GC MKN-45 $\left(1 \times 10^{5}\right)$ cells were seeded in $100 \mu 1$ RPMI-1640 medium supplemented with 10\% FBS (both from Gibco, Grand Island, NY, USA) in 96-well plates and cultured overnight. The medium was replaced with fresh RPMI-1640 and ACBP (induced or normal), L-OHP alone or the combination of anticancer bioactive peptides and oxaliplatin $(\mathrm{A}+\mathrm{L})$ at different concentrations (Fig. 1A). After a further incubation for $24 \mathrm{~h}, 20 \mu \mathrm{l}$ of $5 \mathrm{mg} / \mathrm{ml}$ MTT was added to each well for $4 \mathrm{~h}$. The medium was discarded, $150 \mu \mathrm{l}$ of dimethyl sulfoxide was added for $30 \mathrm{~min}$, and the absorbance of the solution was measured at $490 \mathrm{~nm}$ (OD). The tumor inhibition rate (IR) was calculated as follows: $\% \mathrm{IR}=\left[100-\left(\mathrm{OD}_{\text {test }}-\mathrm{OD}_{\text {black }}\right) /\left(\mathrm{OD}_{\text {control }}-\mathrm{OD}_{\text {black }}\right)\right] \mathrm{x} 100$, where $\mathrm{OD}_{\text {test }}$ is the absorbance value of the test sample, $\mathrm{OD}_{\text {control }}$ is the absorbance value of the control group, and $\mathrm{OD}_{\text {black }}$ is the absorbance value of the blank sample. All experiments were performed in triplicate (18).

Dose-dependent expression of cytochrome c and caspase-9 in MKN-45 cells. Total RNA was extracted from MKN-45 cells using TRIzol reagent according to the manufacturer's instructions (Takara Biomedical Technology Co., Ltd., Beijing, China). After spectrophotometric quantification, $1 \mathrm{mg}$ of total RNA was used to synthesize first-strand cDNA with the Revert Aid H Minus First Strand cDNA synthesis kit (Fermentas, Glen Burnie, MD, USA). Real-time RT-PCR reactions were carried out on an Mx3000P real-time PCR system (Stratagene, La Jolla, CA, USA). To correct for experimental variations between samples, glyceraldehyde-3-phosphate dehydrogenase (GAPDH) was used as the internal control. Primers were designed and synthesized by Sangon Biotech Co., Ltd. (Shanghai, China), as shown in Table I. The expression of caspase- 9 and cytochrome $c$ in the MKN-45 cells was detected. The PCR program was as follows: i) initial denaturation at $95^{\circ} \mathrm{C}$ for $5 \mathrm{~min}$; ii) 35 cycles of denaturation at $95^{\circ} \mathrm{C}$, annealing at $60^{\circ} \mathrm{C}$, and elongation at $60^{\circ} \mathrm{C}$ for $30 \mathrm{sec}$; and iii) a final extension at $60^{\circ} \mathrm{C}$ for $40 \mathrm{sec}$. RT-PCR was performed using the Taq-Man Gene Expression Assay protocol (Applied Biosystems, Waltham, MA, USA). The relative quantification and expression of caspase-9 and cytochrome $c$ in the cell lines were normalized using GAPDH by the $2^{-\Delta \Delta C T}$ method (19).

Hematoxylin and eosin $(H \& E)$ staining of $M K N-45$ cells in a dose-dependent manner. $\mathrm{H} \& \mathrm{E}$ was used to stain MKN-45 cells after culture in RPMI-1640 medium following each treatment. The sterile coverslips were placed in 6-well plates, and each coverslip was treated with drops of $4 \%$ polylysine $100 \mu \mathrm{l}$ at $37^{\circ} \mathrm{C}$. The 6 -well plates were removed after $6 \mathrm{~h}$, and then human GC MKN-45 cells $\left(1 \times 10^{5}\right.$ cells $\left./ \mathrm{ml}\right)$ were seeded in a 6 -well plate and incubated at $37^{\circ} \mathrm{C}$. After $8 \mathrm{~h}$ of incubation, the cell culture solution was discarded, and $1 \mathrm{ml}$ of the cell culture solution containing different drugs was added (A, negative control (NS); B, $20 \mu \mathrm{g} / \mathrm{ml}$ induced ACBP; C, $30 \mu \mathrm{g} / \mathrm{ml}$ induced ACBP; D, $20 \mu \mathrm{g} / \mathrm{ml} \mathrm{L}-\mathrm{OHP}$; $\mathrm{E}, 20 \mu \mathrm{g} / \mathrm{ml}$ induced ACBP $+20 \mu \mathrm{g} / \mathrm{ml} \mathrm{L}-\mathrm{OHP} ; \mathrm{F}, 30 \mu \mathrm{g} / \mathrm{ml}$ induced $\mathrm{ACBP}+20 \mu \mathrm{g} / \mathrm{ml} \mathrm{L-OHP)}$ and cultured for $24 \mathrm{~h}$. 

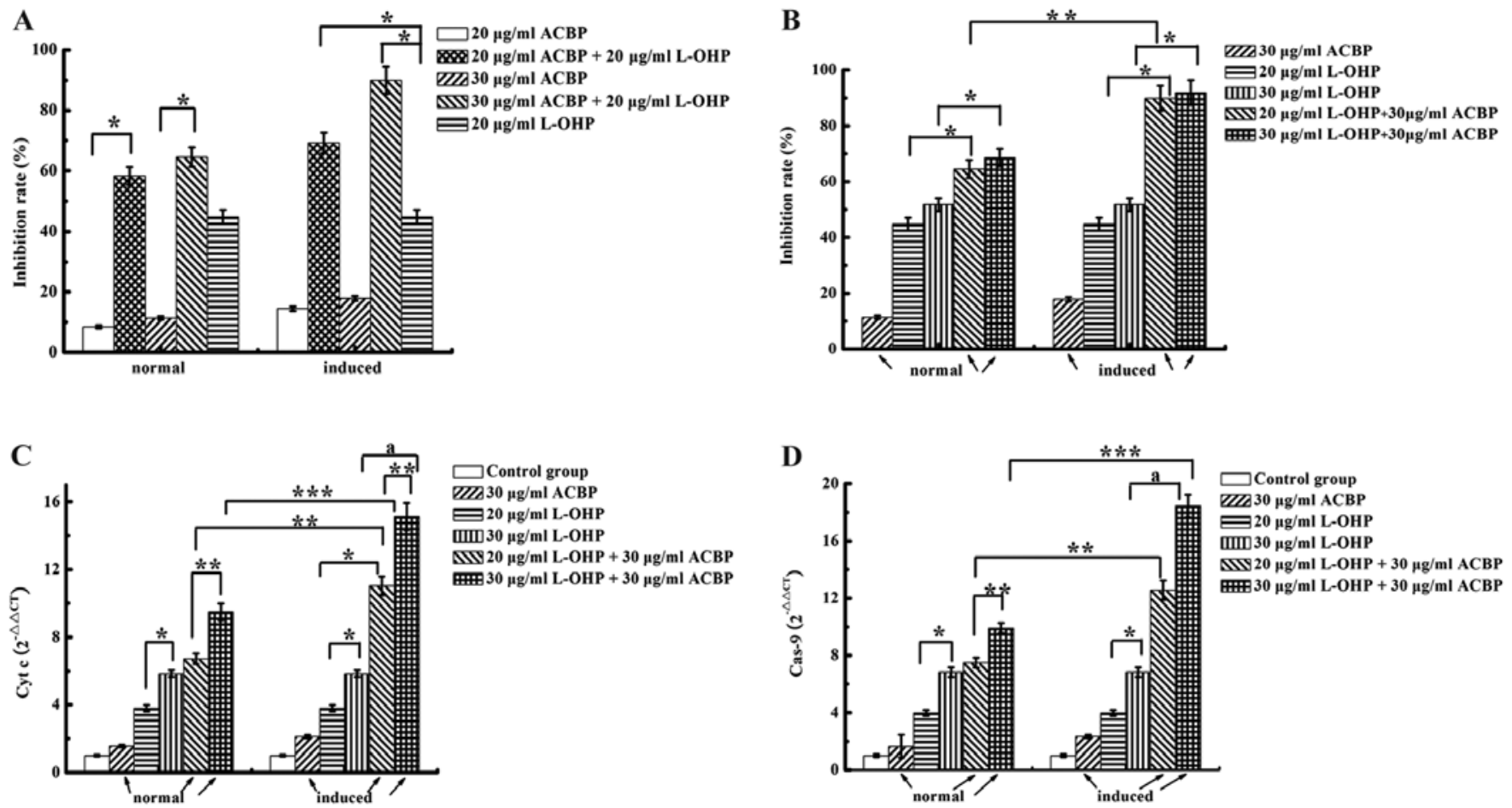

Figure 1. (A and B) Dose-dependent inhibitory effect and expression of cytochrome $c$ (Cyt $c$ ) and caspase-9 (Cas-9) of the anticancer drugs in human GC cells $(\mathrm{MKN}-45)$. Data are shown as the mean $\pm \mathrm{SD}$ of three independent experiments. ${ }^{\mathrm{P}}<0.05$ vs. control. Dose-dependent expression of $(\mathrm{C}) \mathrm{Cyt} c$ and (D) Cas- 9 using the $2^{-\triangle \Delta C T}$ method. Data are shown as the mean $\pm \mathrm{SD}$ of three independent experiments. " $\mathrm{P}<0.05 \mathrm{vs.} 30 \mu \mathrm{g} / \mathrm{ml}$ normal or induced ACBP; ${ }^{* *} \mathrm{P}<0.05$ vs. $20 \mu \mathrm{g} / \mathrm{ml} \mathrm{L-OHP}+30 \mu \mathrm{g} / \mathrm{ml}$ normal ACBP; ${ }^{* * *} \mathrm{P}<0.05$ vs. $30 \mu \mathrm{g} / \mathrm{ml} \mathrm{L}-\mathrm{OHP}+30 \mu \mathrm{g} / \mathrm{ml}$ normal ACBP; ${ }^{2} \mathrm{P}<0.05 \mathrm{vs} .30 \mu \mathrm{g} / \mathrm{ml} \mathrm{L}-\mathrm{OHP}$. GC, gastric cancer; SD, standard deviation; ACBP, anticancer bioactive peptide; L-OHP, oxaliplatin.

Table I. Primer sequences and amplification fragment of caspase- $3,-8$ and -9 , cytochrome $c$ and GAPDH.

\begin{tabular}{llll}
\hline $\begin{array}{l}\text { Target } \\
\text { gene }\end{array}$ & & \multicolumn{1}{c}{ Primer sequences } & $\begin{array}{c}\text { AF } \\
(\mathrm{kbp})\end{array}$ \\
\hline Caspase-3 & F & 5'-AGAACTGGACTGTGGCATTGA & 191 \\
& R & 5'-GCTTGTCGGCATACTGTTTCA & \\
Caspase-8 & F & 5'-GGATGGCCACTGTGAATAACTG & 101 \\
& R & 5'-TCGAGGACATCGCTCTCTCA & \\
Caspase-9 & F & 5'-GTCCTACTCTACTTTCCCAGGTTTTG & 148 \\
& R & 5'-gTgAgCCCACTgCTCAAAgAT & \\
Cyt $c$ & F & 5'-GAGCGGGAGTGTTCGTTGT & 165 \\
& R & 5'-CTTCCGCCCAAAGAGACCAT & \\
GAPDH & F & 5'-TCCACCACCCTGTTGCTGTA & 452 \\
& R & 5'-ACCACAGTCCATGCCATCAC & \\
\end{tabular}

AF, amplification fragment; Cyt $c$, cytochrome $c$; GAPDH, glyceraldehyde-3-phosphate dehydrogenase; $F$, forward; R, reverse.

Each well was washed three times with phosphate-buffered saline (PBS) and were fixed in $95 \%$ ethanol for $30 \mathrm{~min}$, and washed with PBS one time for $2 \mathrm{~min}$. After incubation, the cells were fixed and stained with H\&E for 15 min. Random selected fields were photographed under a light microscope. For cell viability measurements, H\&E-stained cells displaying nuclear condensation and fragmentation were counted as apoptotic cells. Observations were obtained from at least three independent experiments.
Tumor modeling in vivo. Human MKN-45 GC cells were cultured with RPMI-1640 medium containing $10 \%$ heat-inactivated FBS, $100 \mathrm{mg} / \mathrm{ml}$ streptomycin, and $100 \mathrm{U} / \mathrm{ml}$ of penicillin at $37^{\circ} \mathrm{C}$ in a $5 \% \mathrm{CO}_{2}$ incubator. The MKN-45 cells were harvested with $0.05 \%$ trypsin-EDTA and washed with $1 \mathrm{ml}$ of PBS. Cells $\left(1 \times 10^{7}\right.$ cells) were injected subcutaneously into the right ventral flanks of 6-week-old male BALB/c nude mice (Shizuoka Laboratory Animal Center, Hamamatsu, Japan) that were maintained under specific pathogen-free conditions. After 15 days of inoculation, the tumor diameter reached $1.5 \mathrm{~cm}$, and was used as the formal experimental tumor strain for tumor tissue block transplantation.

Tumor xenograft experiments. The tumor tissues were obtained from the donor mice, put into physiological saline to remove necrotic tissue and then gently cut into pieces of $2-3 \mathrm{~mm}^{3}$ on ice. A total of 75 male BALB/c mice (4-5 weeks; average weight, $16 \mathrm{~g}$ ) were used for the subcutaneous transplantation of human GC MKN-45 tumors. The mice were maintained under specific pathogen-free conditions and were provided with food and water until tumor growth. Next, we determined the antitumor effect of induced ACBP and $\mathrm{A}+\mathrm{L}$ on $\mathrm{BALB} / \mathrm{c}$ nude mice in the following experiment. We choose 24 male $\mathrm{BALB} / \mathrm{c}$ nude mice. The induced ACBP and the combination of induced ACBP and L-OHP inhibited cancer cell growth at high concentrations ( $30 \mu \mathrm{g} / \mathrm{ml}$ ACBP $+20 \mu \mathrm{g} / \mathrm{ml} \mathrm{L-OHP})$. This suggested that at these concentrations the induced ACBP acts on the MKN-45 cells and also leads to apoptosis. Therefore, the induced ACBP was used for the following analysis. Therefore, a total of $24 \mathrm{BALB} / \mathrm{c}$ mice (4-5 weeks of age; 
average weight, $16 \mathrm{~g}$ ) were randomized into four groups ( $\mathrm{n}=6$ per group, named R1, R2, R3, R4, R5 and R6, respectively): negative control with an intraperitoneal injection of $0.5 \mathrm{ml}$ normal saline ( $0.9 \%$ sodium chloride solution); injection of $0.5 \mathrm{ml}, 30 \mu \mathrm{g} / \mathrm{ml}$ ACBP (induced) alone; $0.5 \mathrm{ml}, 20 \mu \mathrm{g} / \mathrm{ml}$ L-OHP alone; or total $0.5 \mathrm{ml}\left(\mathrm{V}_{\mathrm{ACBP}}: \mathrm{V}_{\mathrm{L}-\mathrm{OHP}}=1: 1\right), 30 \mu \mathrm{g} / \mathrm{ml}$ ACBP (induced) $+20 \mu \mathrm{g} / \mathrm{ml} \mathrm{L-OHP}(\mathrm{A}+\mathrm{L})$, respectively, into the right anterior flank via the tail vein each week for two times. All treatments were administered on day 3, 7, 10, 14. The dose of L-OHP (10 mg/kg) was chosen by our experiment screening from 1 to $30 \mu \mathrm{g} / \mathrm{ml}$, which was chosen based on a similar previous study from 75 to $130 \mathrm{mg} / \mathrm{m}^{2}(6,13)$, while the dose of ACBP was chosen based on our own previous study (17). The tumor volume (V) was measured every 3 days by a vernier caliper after the tumors formed. The minimum width (a) and ribbon width (b) of the tumor were recorded, and the tumor volume was calculated as $\mathrm{V}=\mathrm{ab}^{2} / 2$.

Three weeks after inoculation, the blood was obtained from the eyeball; thereafter, the nude mice were sacrificed by cervical vertebra dislocation, and the tumor, liver, and spleen tissues were immediately weighed and fixed by paraformaldehyde. The blood and tumor sections were analyzed by flow cytometry. Liver and spleen tissue slices were analyzed by $\mathrm{H} \& \mathrm{E}$ staining, and additional tumor sections were analyzed by immunohistochemistry. Normal nude mice (non-tumor xenograft nude mice) were used as a control group. No side-effects, including weight loss, skin reaction, or infection, were observed throughout the treatment periods. The inhibitory tumor rates were calculated as $\left(\mathrm{W}_{\text {control }}-\mathrm{W}_{\text {experiment }}\right) / \mathrm{W}_{\text {control }} \times 100 \%$. All animal experiments were performed with the approval of the Ethics Committee for Animal Experiments of Inner Mongolia Medical University.

$H \&$ E staining of liver and spleen tissues. The fixed tissues were dehydrated through a graded ethanol series $(30,50,70,80,90$, 95 , and $100 \%$ ), immersed in liquid wax, and embedded in epoxy resin. Tissue blocks were sectioned (5- $\mu \mathrm{m}$ thickness) using a Leica RM 2016 diamond saw microtome (Leica Biosystems Nussloch GmbH, Nussloch, Germany) and collected on coated slides. The samples were prepared for histopathological analysis using H\&E staining. The samples were then rinsed three times in PBS and incubated in $4 \%$ diaminobenzidine at room temperature. Images were acquired using an optical microscope connected to a CCD camera (DP25; Olympus, Tokyo, Japan).

Propidium iodide (PI) staining and flow cytometry for cell cycle analysis and apoptotic rate. Briefly, tumor cell suspensions $\left(1 \times 10^{6}\right.$ cells) were prepared by cutting the tumor tissue with scissors, filtering it through 500-mesh copper mesh, fixing in $70 \%$ ethanol, centrifugation, and washing overnight. An appropriate amount of PBS and PI containing RNase was added. Cells $\left(1 \times 10^{6}\right)$ were washed twice with HEPES-buffered saline, treated with trypsin, and fixed in cold $70 \%$ ethanol at $4^{\circ} \mathrm{C}$ for $30 \mathrm{~min}$. Cell pellets were collected and incubated in $1 \mathrm{ml}$ $50 \mathrm{mg} / \mathrm{ml}$ PI. Flow cytometric evaluation was conducted within 5 min using an EPICS XL-MCL FACScan (Becton-Dickinson, Mountain View, CA, USA). The DNA contents were analyzed with the MultiCycle software for Windows (Phoenix Flow Systems, San Diego, CA, USA) (20-22).
Immunohistochemistry. Subcutaneous tumors formed after injection of tumor cells into the male nude mice were removed and fixed in $10 \%$ buffered formalin for $24 \mathrm{~h}$. Formalin-fixed and paraffin-embedded sections $(4 \mu \mathrm{m})$ were used for immunohistochemistry $(23,24)$. The sections were stored dry until use. After pre-incubation with $0.3 \%$ hydrogen peroxide in methanol for $30 \mathrm{~min}$ to block endogenous peroxidase activity, the sections were rinsed in PBS. Caspase-3, -8, -9, or cytochrome $c$ were visualized immunohistochemically by the MaxVision method using 1:100 rabbit anti-caspase-9 or -cytochrome $c$ antibody (Leica Biosystems Nussloch $\mathrm{GmbH}$ ) or 1:50 rabbit anti-caspase-3 or -8 antibody (Cell Signaling Technology, Inc.) and the immunohistochemical MaxVision kit (product no. KIT-5010/5020/5030), antigen repair fluid (product no. MVS-0098/0099), and DAB color reagent box (product no. DAB-0031/1031) according to the manufacturer's protocol (China). The sections were rinsed and incubated with the secondary antibody (goat biotinylated anti-rabbit IgG antibody). Sections were washed with PBS, and the peroxidase reaction was developed by incubating the sections in diaminobenzidine solution containing $0.003 \%$ hydrogen peroxide and $10 \mathrm{mM}$ sodium azide followed by a Mayer's hematoxylin counterstain. Sections were then dehydrated through graded ethanol solutions (70-100\%). For quantification, the number of positive cells in each randomly selected field $\left(\sim 100,000 \mu \mathrm{m}^{2}\right)$ was counted at $\mathrm{x} 400$ magnification. Only cells stained precisely were counted as positive to avoid counting non-specific staining. Standards of grading are according to the conventional semi-quantitative scoring method (25).

RNA isolation and RT-PCR. Total RNA was extracted from tumor tissue using the TRIzol reagent according to the manufacturer's instructions. After spectrophotometric quantification, $1 \mathrm{mg}$ of total RNA was used to synthesize first-strand cDNA with the Revert Aid H Minus First Strand cDNA synthesis kit (Fermentas). Real-time RT-PCR reactions were carried out on an Mx3000P real-time PCR system (Stratagene). To correct for the experimental variations between samples, GAPDH was used as the internal control. Primers were designed and synthesized by the Sangon Biotech Co., Ltd., as shown in Table I. The expression of caspase-3 p20 (N-19) (sc-1226), caspase-8 p18 (D-8) (sc-5263), caspase-9 (9CSP03) (sc-73548), and cytochrome $c$ (A-8) (sc-13156) (Santa Cruz Biotechnology, Inc., Santa Cruz, CA, USA) in the tumor tissue was detected. The PCR program was as follows: i) initial denaturation at $95^{\circ} \mathrm{C}$ for 5 min; ii) 35 cycles of denaturation at $95^{\circ} \mathrm{C}$, annealing at $60^{\circ} \mathrm{C}$, and elongation at $60^{\circ} \mathrm{C}$ for $30 \mathrm{sec}$; and iii) a final extension at $60^{\circ} \mathrm{C}$ for $40 \mathrm{sec}$. RT-PCR was performed using the Taq-Man Gene Expression Assay protocol (Applied Biosystems). The mRNA from tumor tissue was typed with BstUI, and the digestion products were resolved by $2 \%$ agarose gel electrophoresis with ethidium bromide staining and UV light detection. The results were documented by digital camera and stored as computer files in BioCapt software (Vilbert-Lourmant, Marne LaValle, France).

Statistical analysis. The data are expressed as the mean \pm standard deviation (SD). Student's t-tests and one-way analysis of variance (ANOVA) were performed for determination of P-values with SPSS version 18.0 software (SPSS, Inc., 
Chicago, IL, USA). All experiments were performed at least three times unless otherwise indicated. $\mathrm{P}<0.05$ was considered statistically significant.

\section{Results}

High levels of induced $A C B P$ and $L-O H P$ increase the IR in MKN-45 cells. The effects of ACBP or induced ACBP and L-OHP on cytotoxicity and apoptosis in MKN-45 cells are shown in Fig. 1A. Comparison of the single-drug treatments indicated significantly different growth IRs. The direct inhibitory effects on MKN-45 cells were as follows: $20 \mu \mathrm{g} / \mathrm{ml}$ L-OHP $>$ induced ACBP $>$ normal ACBP $>$ control group. Growth IRs were dose-dependent; $30 \mu \mathrm{g} / \mathrm{ml}$ normal or induced ACBP had a significantly greater inhibitory effect than $20 \mu \mathrm{g} / \mathrm{ml}$ normal or induced ACBP $(\mathrm{P}<0.05)$. Furthermore, normal and induced ACBP + L-OHP each had a significantly higher IR than L-OHP alone $(\mathrm{P}<0.05)$. As shown in Fig. 1B induced ACBP combined with L-OHP had a significantly higher IR than normal ACBP combined with L-OHP $(\mathrm{P}<0.05)$.

Induced $A C B P$ in combination with $L-O H P$ increases caspase-9 and cytochrome c expression in MKN-45 cells. Combining ACBP and L-OHP is a major strategy for GC successful treatment. To investigate the mechanism by which $\mathrm{A}+\mathrm{L}$ enhances the apoptosis of GC cells, we examined the expression levels of several related proteins (cytochrome $c$ and caspase-9) by qRT-PCR (Fig. 1C and D). The mRNA expression levels of caspase-9 and cytochrome $c$ in the ACBP-treated MKN-45 cells were significantly higher than that noted in the control-treated cells. Compared with normal and induced ACBP, 20 or $30 \mu \mathrm{g} / \mathrm{ml} \mathrm{L-OHP} \mathrm{upregulated} \mathrm{caspase-9} \mathrm{and}$ cytochrome $c$ expression. The combination of ACBP with different concentrations of L-OHP showed statistically significant differences for caspase- 9 and cytochrome $c$ expression. For example, treatment with $30 \mu \mathrm{g} / \mathrm{ml}$ ACBP $+30 \mu \mathrm{g} / \mathrm{ml}$ L-OHP upregulated caspase- 9 and cytochrome $c$ compared to treatment with $30 \mu \mathrm{g} / \mathrm{ml} \mathrm{ACBP}+20 \mu \mathrm{g} / \mathrm{ml} \mathrm{L}-\mathrm{OHP}$ $(\mathrm{P}=0.000)$. The MKN-45 cells treated with induced ACBP in combination with L-OHP exhibited higher caspase-9 and cytochrome $c$ expression than the normal ACBP in the combination treatment; the differences were statistically significant $(\mathrm{P}<0.05)$. Therefore, except for the negative control, the test group and positive control could induce the expression of caspase-9 and cytochrome $c$, and the expression levels were as follows: $30 \mu \mathrm{g} / \mathrm{ml} \mathrm{ACBP}+30 \mu \mathrm{g} / \mathrm{ml} \mathrm{L}-\mathrm{OHP}>30 \mu \mathrm{g} / \mathrm{ml}$ $\mathrm{ACBP}+20 \mu \mathrm{g} / \mathrm{ml} \mathrm{L}-\mathrm{OHP}>30 \mu \mathrm{g} / \mathrm{ml} \mathrm{L}-\mathrm{OHP}>20 \mu \mathrm{g} / \mathrm{ml}$ L-OHP $>$ induced ACBP $>$ normal ACBP. These results indicate that $\mathrm{A}+\mathrm{L}$ enhances apoptosis. These results demonstrate that not only do ACBP and L-OHP induce apoptosis by activating the caspase- 9 and cytochrome $c$ pathway but also that $\mathrm{A}+\mathrm{L}$ has coordinated effects.

Induced ACBP combined with L-OHP promotes apoptosis in $M K N-45$ cells. Based on the above analysis, induced ACBP or induced ACBP in combination with L-OHP caused higher caspase-9 and cytochrome $c$ expression than normal ACBP or combination therapy with normal ACBP. Therefore, we further examined the dose dependence of apoptosis by the induced ACBP or combination therapy compared to L-OHP and NS in the MKN-45 cell lines using H\&E staining. H\&E-stained MKN-45 cells are shown in Fig. 2. Cells treated with normal saline exhibited adherent growth and uniform morphology with clear cell contours. In contrast, treatment with $20 \mu \mathrm{g} / \mathrm{ml}$ induced ACBP, $30 \mu \mathrm{g} / \mathrm{ml}$ induced ACBP, or $20 \mu \mathrm{g} / \mathrm{ml} \mathrm{L}-\mathrm{OHP}$ led to inhomogeneous cell sizes and shapes, poor adhesion, and unclear outlines. Furthermore, the higher doses of induced ACBP were more likely to induce apoptosis in the MKN-45 cells, such as MKN-45 cell treatment with $30 \mu \mathrm{g} / \mathrm{ml}$ of induced ACBP, caused poor cell adhesion and increased the number of suspended cells. However, $20 \mu \mathrm{g} / \mathrm{ml}$ ACBP $+20 \mu \mathrm{g} / \mathrm{ml} \mathrm{L-OHP}$ and $30 \mu \mathrm{g} / \mathrm{ml} \mathrm{ACBP}+20 \mu \mathrm{g} / \mathrm{ml} \mathrm{L-OHP}$ reduced cell adherence to the wall, increased suspended cells, and exhibited nuclear condensation and unclear contours. Therefore, the combination of induced ACBP and L-OHP induced the apoptosis in MKN-45 cells more effectively than induced ACBP or L-OHP alone.

Antitumor efficacy and quality of life induced by $A C B P$ and combination therapy with induced $A C B P$ and $L-O H P$ in a xenograft nude mouse model. A xenograft nude mouse model was established by subcutaneous inoculation of human gastric MKN-45 cancer cells. The morphology of the tumor and tumor weight were measured, calculated at the end of treatment, and the statistical significance of the tumor weight was examined (Fig. 3A). The measured tumor weights are shown in Fig. 3B. Due to the differences between the inhibition tumor rate and the IR in MKN-45 cells after treatment with ACBP or L-OHP in vivo and in vitro, the tumor weights decreased in the L-OHP group compared with the NS and ACBP groups; the changes were not statistically significant $(P>0.05)$. The differences, which mainly reflect nerve immune regulation, individual differences in the nude mice and regulating the function of ACBP in vivo, identified the inhibitory role of L-OHP on the quality of life of the nude mice. Because the tumor sizes were unregulated, the differences in the tumor volume $(\mathrm{V})\left(\mathrm{V}=\mathrm{ab}^{2} / 2\right.$; $\mathrm{a}$ is the minimum width and $\mathrm{b}$ is the ribbon width) in the L-OHP and ACBP alone groups were not significant $(\mathrm{P}>0.05)$; this volume was significantly decreased in the $\mathrm{A}+\mathrm{L}$ group $(\mathrm{P}<0.05)$ (Fig. 3C). Fig. 3D shows the rate of tumor growth with different drug treatments. Compared with the negative control, ACBP, L-OHP, and A+L significantly inhibited tumor growth. The percentages of growth inhibition for ACBP and L-OHP were 5.69 and $30.61 \%$, respectively, whereas inhibition increased to $47.06 \%$ for $\mathrm{A}+\mathrm{L}$, indicating that GC cells were highly inhibited by the chemotherapeutic agents. When we examined ACBP and $\mathrm{A}+\mathrm{L}$ antitumor activity in vivo, we also observed the quality of life of the tumor-bearing nude mice. Changes in body weight and diet of the nude mice were in response to the quality of life as affected by ACBP and combination treatments. The results showed that ACBP alone increased the food intake and body weight of the nude mice compared with the NS group; the changes were not statistically significant $(\mathrm{P}>0.05)$. Because L-OHP displayed toxicity and side-effects, the food intake and body weights of the nude mice were decreased compared with the ACBP group; the difference was significant $(\mathrm{P}<0.05)$. In contrast, the food intake and body weights of the nude mice treated with $\mathrm{A}+\mathrm{L}$ increased compared with the L-OHP group; the difference was significant $(\mathrm{P}<0.05)$ (Fig. 3E). These results identified 

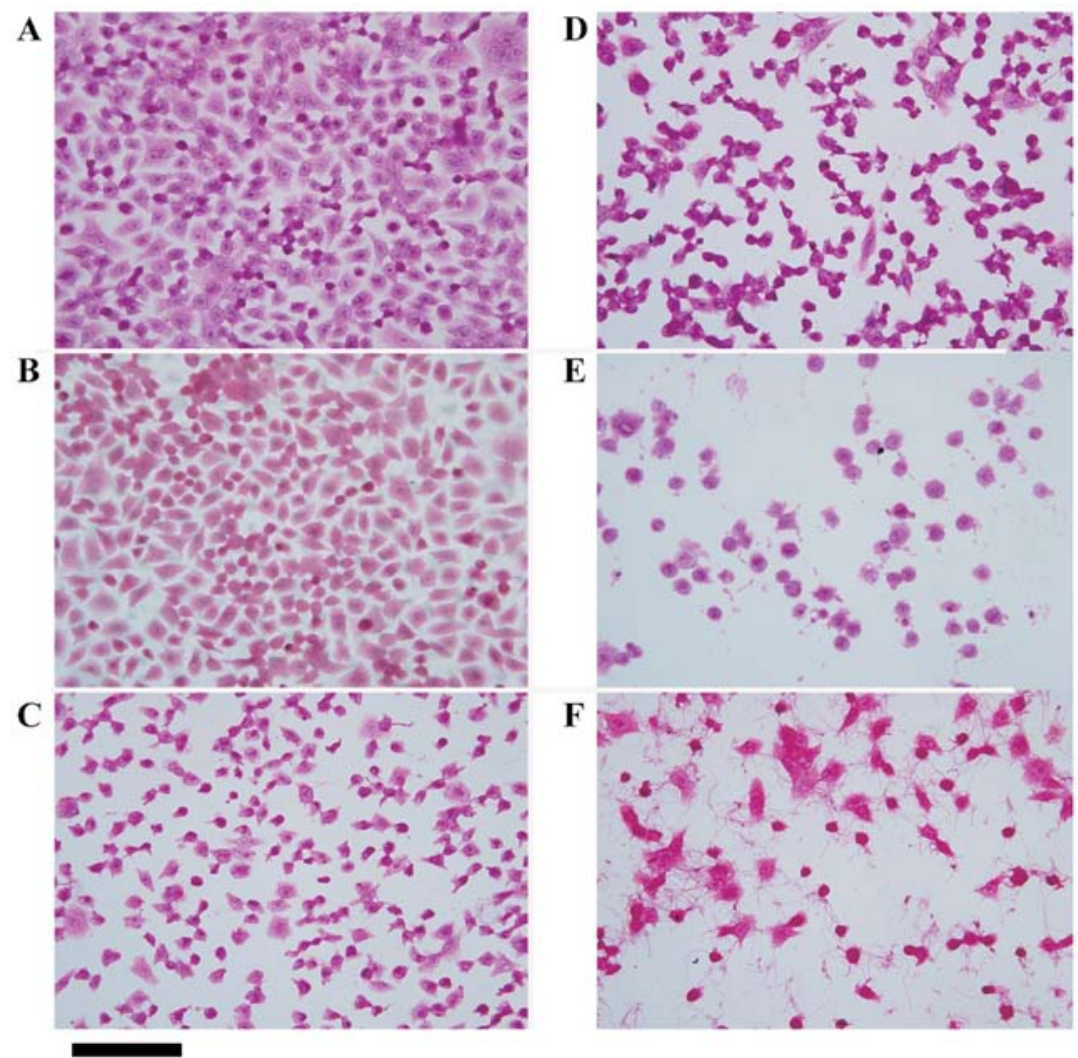

Figure 2. H\&E staining (x400) of treated MKN-45 cells in a dose-dependent manner. (A) Negative control (NS); (B) $20 \mu \mathrm{g} / \mathrm{ml}$ induced ACBP; (C) $30 \mu \mathrm{g} / \mathrm{ml}$ induced ACBP; (D) $20 \mu \mathrm{g} / \mathrm{ml} \mathrm{L-OHP;} \mathrm{(E)} 20 \mu \mathrm{g} / \mathrm{ml}$ induced ACBP $+20 \mu \mathrm{g} / \mathrm{ml} \mathrm{L-OHP;} \mathrm{(F)} 30 \mu \mathrm{g} / \mathrm{ml}$ induced ACBP $+20 \mu \mathrm{g} / \mathrm{ml} \mathrm{L-OHP.} \mathrm{Scale} \mathrm{bar,} 200 \mu \mathrm{m}$. $\mathrm{H} \& \mathrm{E}$, hematoxylin and eosin; NS, normal saline; ACBP, anticancer bioactive peptide; L-OHP, oxaliplatin.
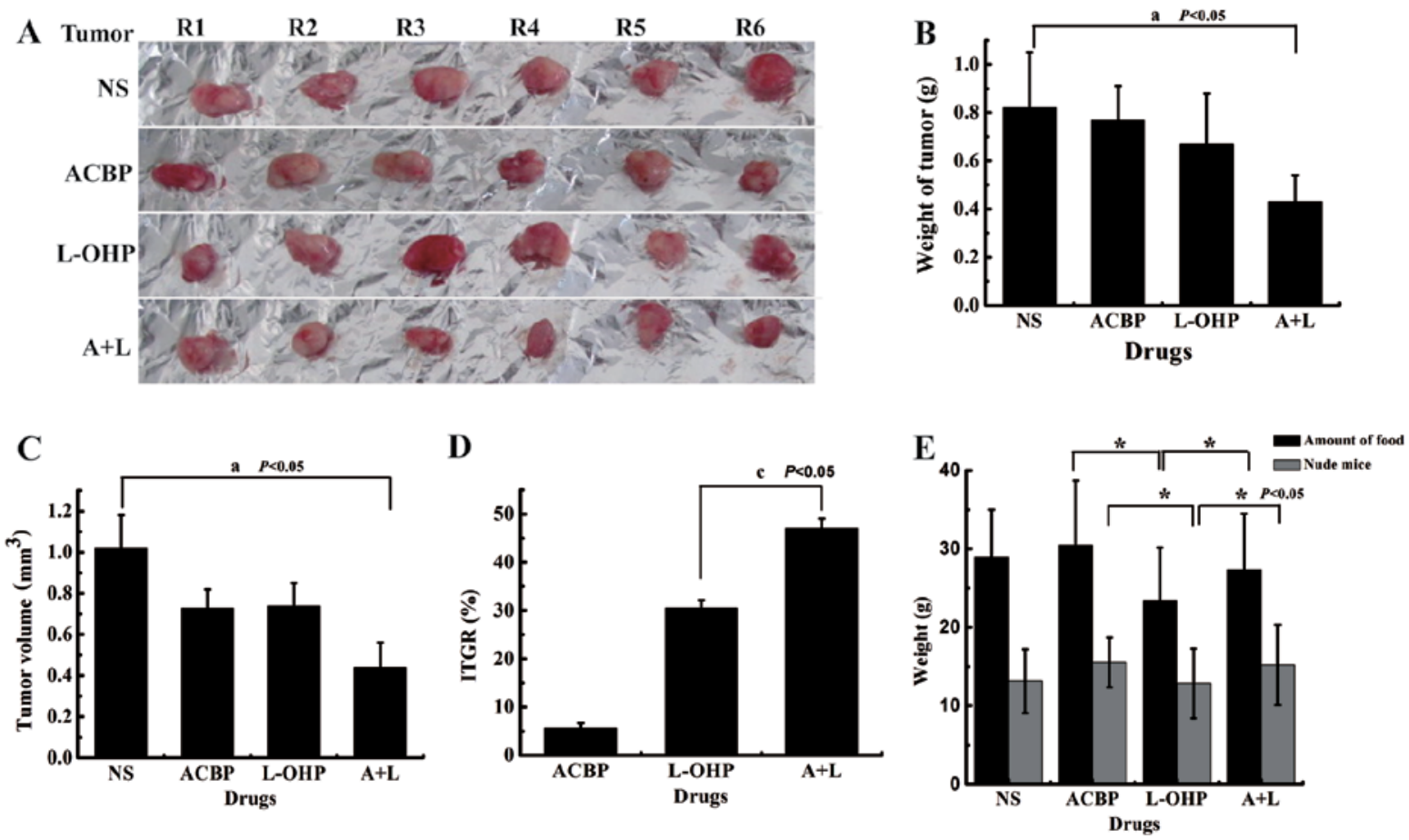

Figure 3. A+L treatment suppresses gastric tumor growth and improves quality of life in the xenograft tumor model. The in vivo tumor growth experiment was established by subcutaneous injection of $1 \times 10^{7} \mathrm{MKN}-45 \mathrm{GC}$ cells. After tumors were palpable and when the sizes of tumors were $\sim 2-3 \mathrm{~mm}^{3}$, the tumor-bearing mice were randomized with six mice $(\mathrm{n}=6)$ each into four groups: control with intraperitoneal injection of saline, injection $\mathrm{ACBP}$ alone $(30 \mu \mathrm{g} / \mathrm{ml}), \mathrm{L}-\mathrm{OHP}$ alone $(20 \mu \mathrm{g} / \mathrm{ml})$, and $\mathrm{A}+\mathrm{L}(30$ and $20 \mu \mathrm{g} / \mathrm{ml})$ via every week for two times, all given the drug at day 3, 7, 10, 14. The final (A) tumor morphology, (B) tumor weight, (C) tumor volume, (D) ITGR, and (E) the diet and weight of nude mice were calculated before the end of the experiment. The data were calculated and are presented as the mean \pm SD. Statistical significance was determined by Student's t-test (statistical difference was indicated as $P<0.05$, when compared with the control group ( $\left.{ }^{a} \mathrm{P}<0.05\right)$, $\mathrm{L}-\mathrm{OHP}\left({ }^{\mathrm{C}} \mathrm{P}<0.05\right)$ and $\mathrm{ACBP}$ or $\mathrm{A}+\mathrm{L}\left({ }^{*} \mathrm{P}<0.05\right)$. A+L, combination of anticancer bioactive peptide and oxaliplatin; GC, gastric cancer; ACBP, anticancer bioactive peptide; L-OHP, oxaliplatin; ITGR, inhibition tumor growth rate; SD, standard deviation. 
A

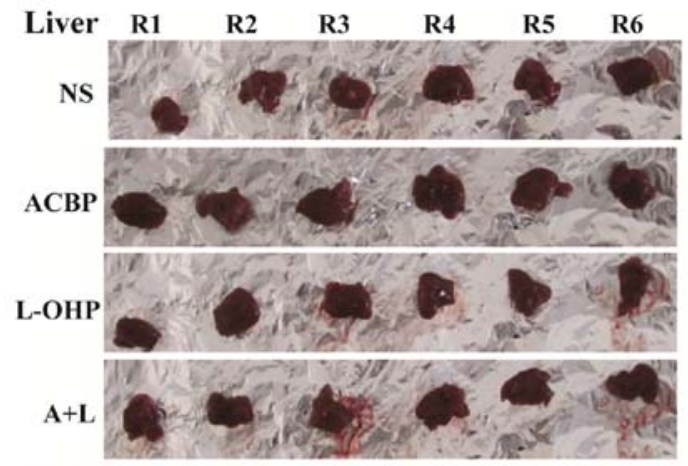

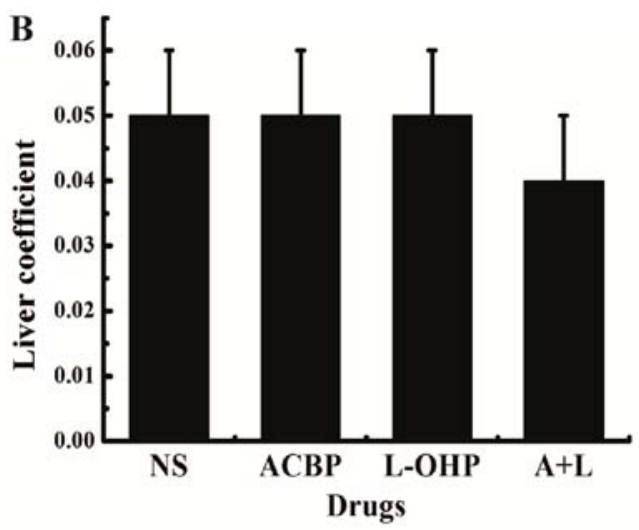
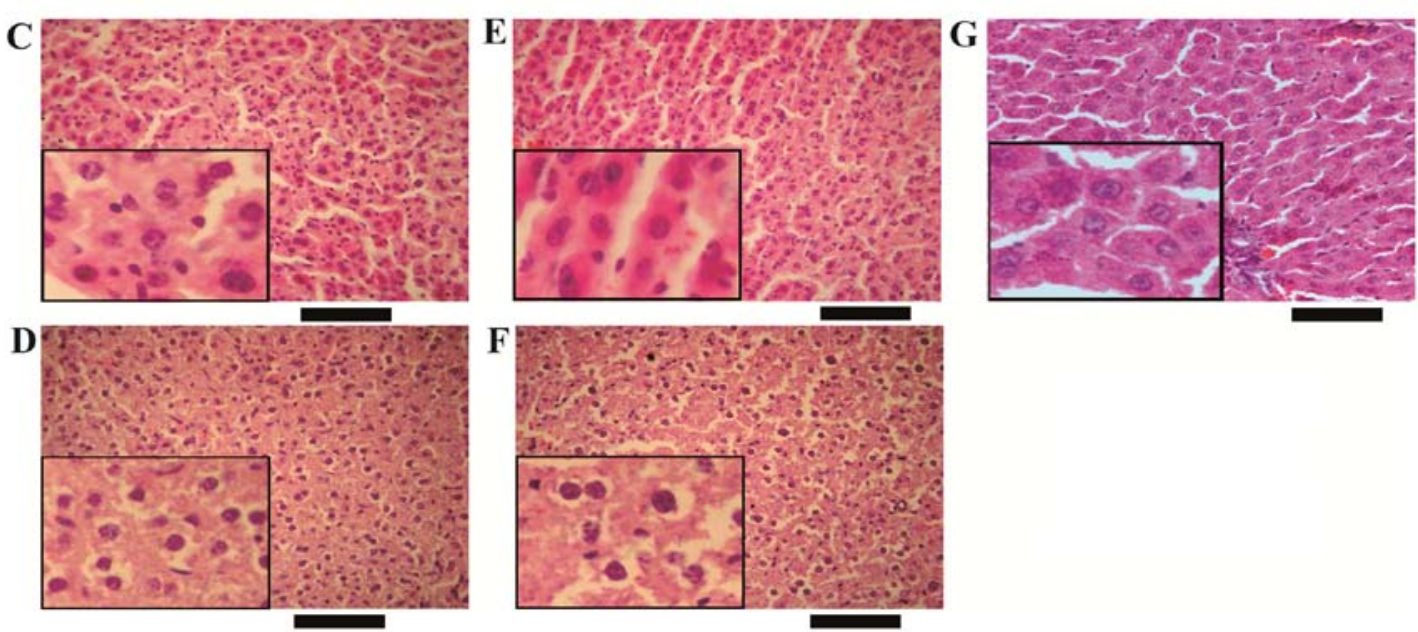

Figure 4. A+L treatment decreases liver weight in the xenograft tumor model. (A) The liver morphology and (B) liver coefficient were calculated before the end of the experiment. The data were calculated and are presented as the mean \pm SD. H\&E staining (x400) of the liver of tumor-bearing nude mice treated with (C) NS, (D) ACBP, (E) L-OHP, (F) A+L and (G) the normal control morphology images of the liver. Scale bar, $200 \mu \mathrm{m}$. A+L, combination of anticancer bioactive peptide and oxaliplatin; SD, standard deviation; H\&E, hematoxylin and eosin; NS, normal saline; ACBP, anticancer bioactive peptide; L-OHP, oxaliplatin.

that ACBP has an important role in reducing the side-effects of chemotherapy, especially by significantly increasing the sensitizing effects of L-OHP, which is an innovative point of this article. The nude mice in the ACBP or A+L group were more active, had good appetite and appearance, and their body weights were closer to that of a normal mouse. The L-OHP group showed little changes in feeding quantity and activity or weight reduction compared to the control group $(\mathrm{P}>0.05)$. Therefore, short-term intermittent use of ACBP alone inhibited tumor growth and improved the quality of life of nude mice. Short-term intermittent use of A+L significantly increased the sensitizing effects of L-OHP and improved the quality of life of the nude mice.

$A+L$ treatment decreases liver weights in xenograft tumor models. The liver and spleen coefficients are directly proportional to the degree of structural destruction. The liver and spleen coefficients are defined as the ratio of the weight of liver/spleen to the weight of the nude mouse. Due to the different weights of the nude mice treated with various drugs (NS, ACBP, L-OHP and A+L), the values of the liver and spleen coefficients are relative. This method is adequate for evaluating the effect of treatment on GCs. Fig. 4A and B shows the effects of the ACBP, L-OHP, and A+L treatments on the livers of tumor-bearing nude mice. H\&E staining has been used as a standard in vivo method to characterize the stem cell-like behaviors (Fig. 4C-F). Black normal saline treatment displayed hepatocellular injury, whereas both free ACBP and L-OHP treatments drastically reduced damage to the hepatocytes with milder effects on hepatic steatosis, loose cytoplasm, eosinophilic change, hepatocellular necrosis, inflammatory cell infiltration, hepatic vein dilation, liver cell damage, and other cable structures. Notably, treatment with A $+\mathrm{L}$ completely inhibited hepatocellular injury compared with L-OHP but had milder effects on the liver steatosis coefficient, loss of cytoplasm, eosinophilic change, hepatocellular necrosis, inflammatory cell infiltration, hepatic vein dilation, and hepatic cord structural changes in liver cells. The results suggest that $\mathrm{A}+\mathrm{L}$ selectively inhibits the growth of GC (Fig. 4B). This result is important as the differences in the liver coefficient are insignificant and the major cause of hepatocellular injury is not related to the drugs.

$A+L$ decreases the spleen coefficient in the xenograft tumor model. The spleen coefficient was measured as an indication of L-OHP systemic toxicity. Fig. 5A shows the spleen damage after treatment with ACBP, L-OHP, and A+L. The results were different from the liver damage results. The spleen coefficient after ACBP treatment decreased significantly $(\mathrm{P}<0.05)$ in comparison with the control (Fig. $5 \mathrm{~B})$; the 
A

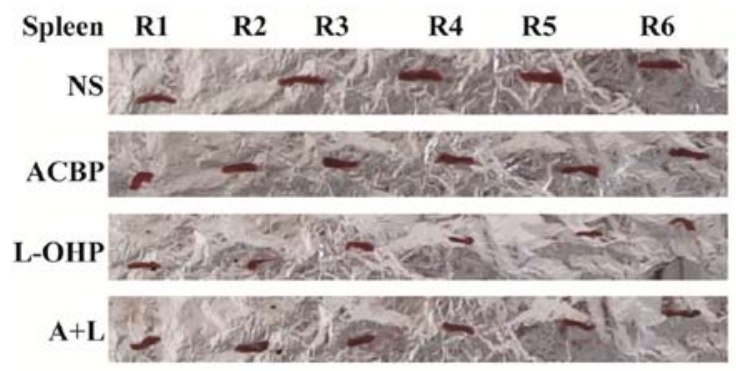

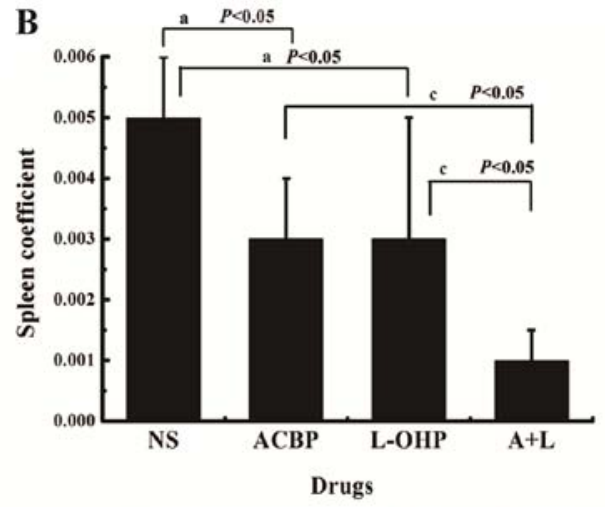
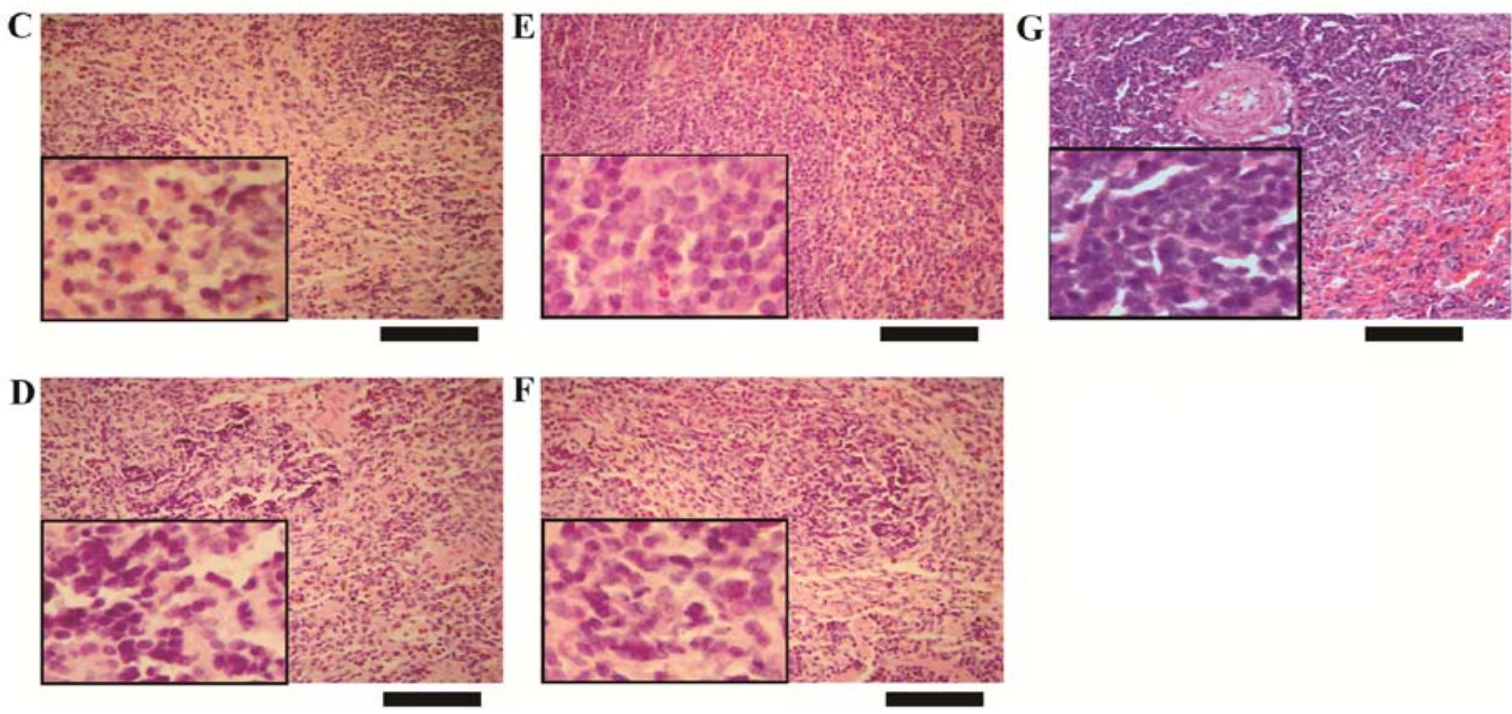

Figure 5. A+L treatment decreases the spleen coefficient in the xenograft tumor model. (A) The spleen morphology and (B) spleen coefficient were calculated before the end of the experiment. The data were calculated and are presented as the mean \pm SD. Statistical significance was determined by Student's t-test [statistical difference was indicated as $\mathrm{P}<0.05$, when compared with (a) the control group, (c) L-OHP or (c) ACBP, $\mathrm{P}<0.05$ ]. H\&E staining ( $\mathrm{x} 400$ ) of the spleen of tumor-bearing nude mice treated with (C) NS, (D) ACBP, (E) L-OHP, (F) A+L and (G) the normal control morphology images of the spleen. Scale bar, $200 \mu \mathrm{m}$. A+L, combination of anticancer bioactive peptide and oxaliplatin; SD, standard deviation; L-OHP, oxaliplatin; ACBP, anticancer bioactive peptide; $\mathrm{H} \& \mathrm{E}$, hematoxylin and eosin; NS, normal saline.

spleen structure showed decreased damage to the malpignian corpuscle and the splenic cords, and the sinus of the red pulp region displayed more sinus cells (Fig. 5C-F). The spleen coefficient after treatment with $\mathrm{A}+\mathrm{L}$ showed a significant reduction compared to L-OHP; expansion of the spleen was not obvious, and the damage to the spleen was significantly decreased (Fig. 5E and F), indicating that the toxicity of L-OHP was decreased by the combination treatment with ACBP. Therefore, short-term intermittent use of $\mathrm{A}+\mathrm{L}$ can significantly reduce the side-effects of chemotherapy.

$A+L$ increases apoptosis and arrests the cell cycle. Because $\mathrm{GC}$ forms solid tumors without capillaries between the cells, which prevents drug penetration to the center of the tumor, a tumor model was established to evaluate the tumor cell cycle effect on apoptosis (Fig. 6A-D). Cytological assays that measure cell cycle revealed that increased amounts of the drugs $(\mathrm{A}+\mathrm{L}, \mathrm{L}-\mathrm{OHP}$, and $\mathrm{ACBP})$ reversed the inhibitory effect of GC cells on the cell cycle. Compared with the control, A+L, L-OHP, and ACBP significantly enhanced the apoptotic rate of the tumor cells $(\mathrm{P}<0.05)$ by increasing the proportion of cells in the $\mathrm{S}$ phase $(\mathrm{P}<0.05)$ (Fig. $6 \mathrm{E}$ and $\mathrm{F})$.
Based on our flow cytometric analysis, $A+L$ significantly increased the proportion of cells in the $\mathrm{G} 2 / \mathrm{M}$ phase $(\mathrm{P}<0.05)$ relative to ACBP or L-OHP alone. Next, we examined the apoptotic rate of the MKN-45 GC cells. A+L and ACBP alone caused $23.15 \pm 3.18$ and $21.56 \pm 5.18 \%$ of the cells to undergo apoptosis, respectively. After treatment with ACBP and A+L, MKN-45 cells displayed higher apoptotic levels compared with the control $(3.24 \pm 0.57 \%)$ or L-OHP $(10.75 \pm 3.05 \%)$, indicating the statistically significant increase in apoptosis $(\mathrm{P}<0.01)$. Compared with the control, ACBP, L-OHP and A+L all resulted in statistically significant increases in apoptosis $(\mathrm{P}<0.01)$. Therefore, $\mathrm{A}+\mathrm{L}$ treatment suppressed the cell cycle in the $\mathrm{S}$ and $\mathrm{G} 2 / \mathrm{M}$ phase and enhanced cellular apoptosis.

Protein expression of cytochrome c, caspase-3, -8, and -9 in GC tissue. Initially, we tested the expression of cytochrome $c$, caspase-3, -8 , and -9 in GC tissues treated with ACBP, L-OHP, or A+L and a matched control (NS control) using immunohistochemical staining (Fig. 7). Observation under an optical microscope showed positive staining for cytochrome $c$, caspase $-3,-8$, and -9 as well as yellow, pale brown or chocolate brown colors. The positive staining for 
A

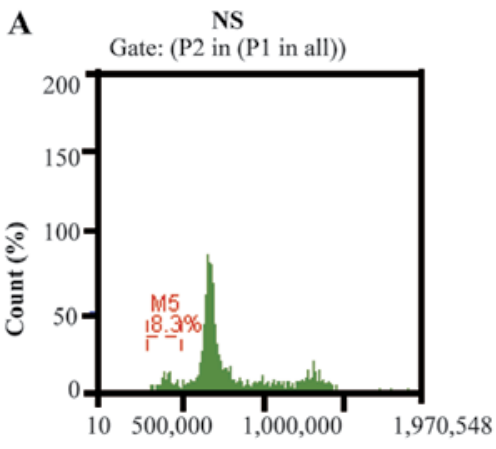

FL2-A

C

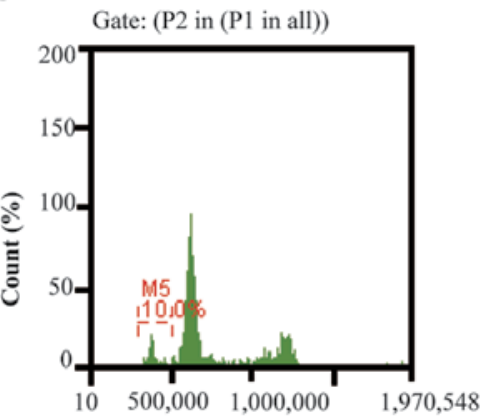

FL2-A

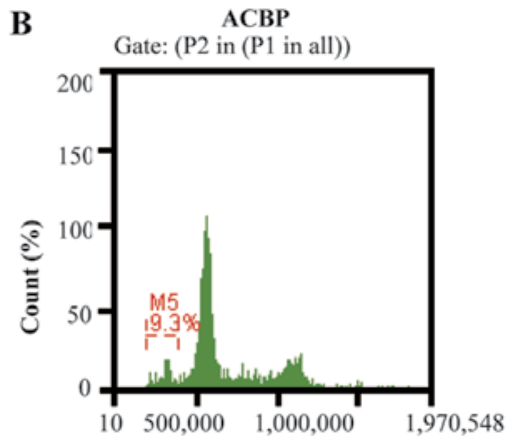

FL2-A

D

$\mathbf{A}+\mathbf{L}$

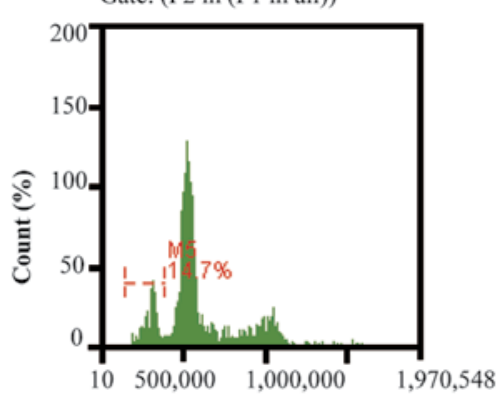

FL2-A

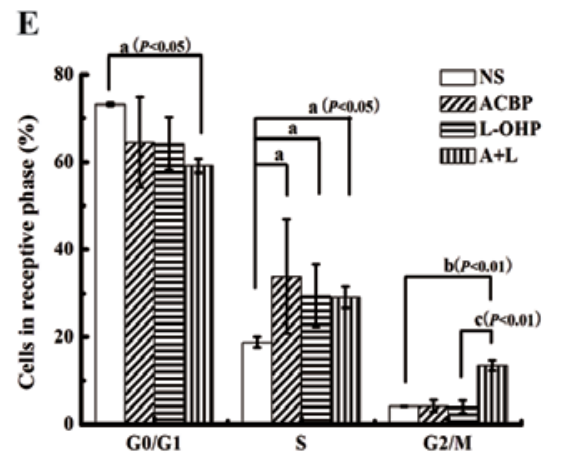

F

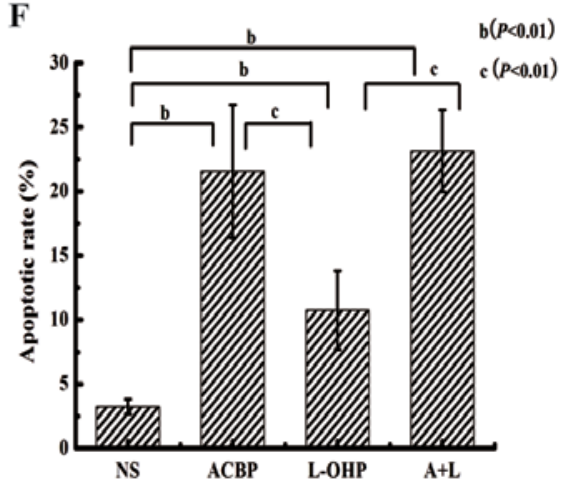

Figure 6. PI staining and flow cytometry for cell cycle analysis and apoptotic rate. (A) The control NS, (B) ACBP alone, (C) L-OHP alone, and (D) A+L effects on MKN-45 cell tumors. (E) Cells in respective cell cycle phase and (F) apoptotic rate were calculated and are presented as the mean \pm SD. Statistical significance was determined by Student's t-test [statistical difference was indicated as $\mathrm{P}<0.05$, when compared with the control group $\left({ }^{\mathrm{a}} \mathrm{P}<0.05\right.$, $\left.{ }^{\mathrm{b}} \mathrm{P}<0.01\right)$, and L-OHP ('P<0.01)]. PI, propidium iodide; NS, normal saline; ACBP, anticancer bioactive peptide; L-OHP, oxaliplatin; A+L, combination of anticancer bioactive peptide and oxaliplatin; SD, standard deviation.

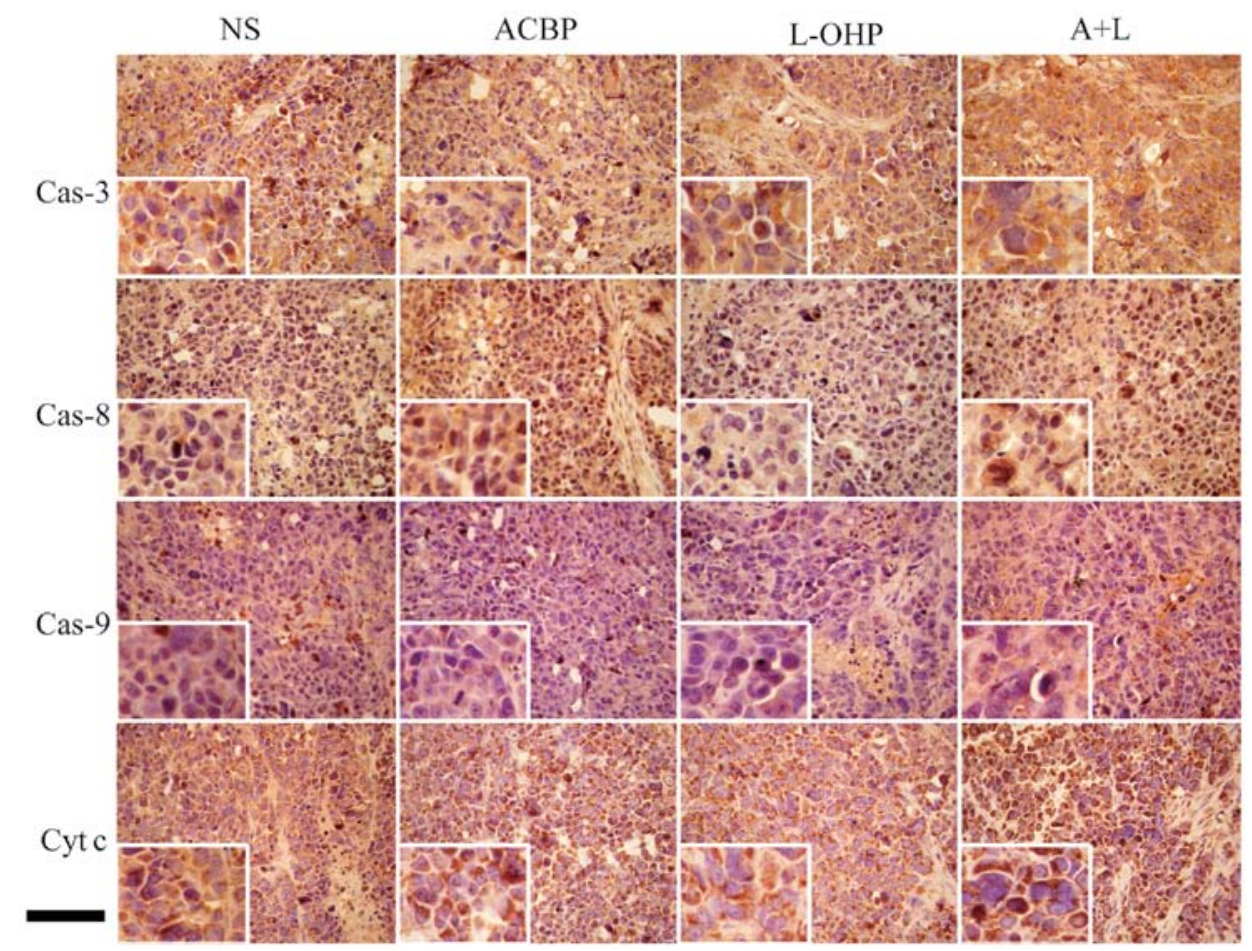

Figure 7. Immunohistochemical staining for caspase-3, caspase-8, caspase-9 and cytochrome $c$ protein expression. Representative images of Cas-3 (first row), Cas-8 (second row), Cas-9 (third row), and Cyt $c$ (fourth row) protein expression in GC tumor tissues treated with NS (first column), ACBP (second column), L-OHP (third column), and A+L (fourth column) by immunohistochemical analysis (x400). Scale bar, $100 \mu \mathrm{m}$. Cas-3, caspase-3; Cas-8, caspase-8; Cas-9, caspase-9; Cyt $c$, cytochrome $c$; GC, gastric cancer; NS, normal saline; ACBP, anticancer bioactive peptide; L-OHP, oxaliplatin; A+L, combination of anticancer bioactive peptide and oxaliplatin. 
A

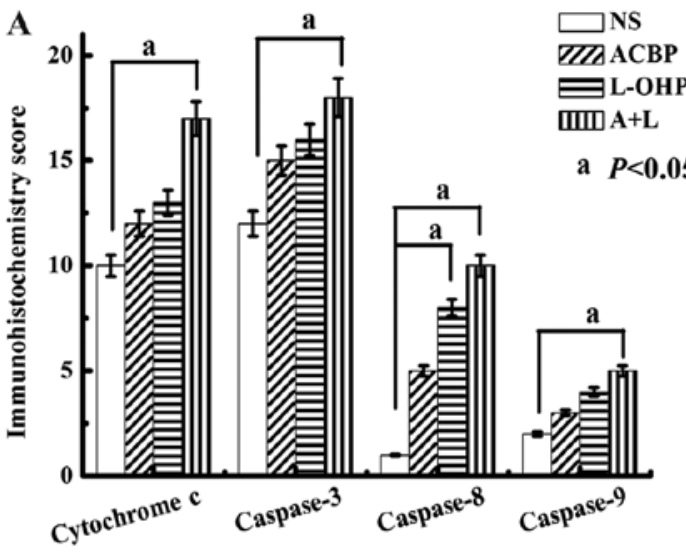

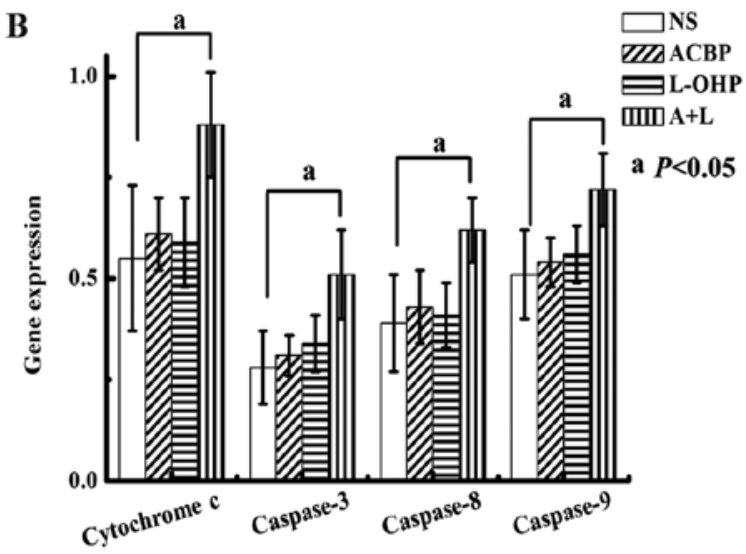

C

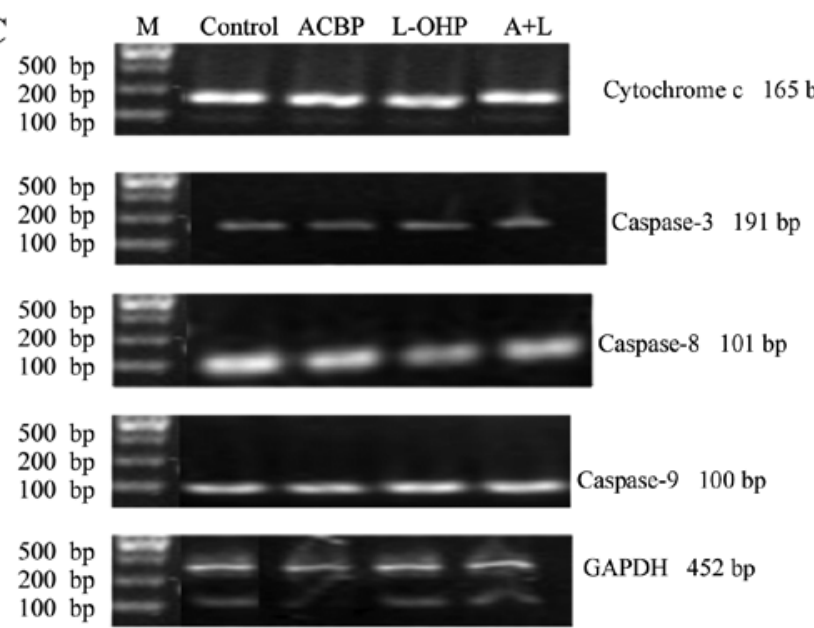

Figure 8. Immunohistochemical score of cytochrome $c$, caspase-3, caspase-8 and caspase-9 protein expression in tumor tissues. (A) The immunohistochemical score was calculated according to the conventional semi-quantitative scoring method. Statistical significance was determined by Student's t-test [statistical difference was indicated as $\mathrm{P}<0.05$, when compared with (a) the control group]. (B) RT-PCR and $2 \%$ agarose gel electrophoresis for Cas-3, Cas- 8 , Cas- 9 and Cyt $c$ gene expressions. The MKN-45 GC cells in the xenograft tumor model were treated with NS (control), ACBP, L-OHP, and A+L for $48 \mathrm{~h}$ for RT-PCR analysis. (C) Cas-3, Cas-8, Cas-9, and Cyt $c$ gene expression in human MKN-45 GC cells was typed with Bst UI and resolved by $2 \%$ agarose gel electrophoresis. Gene expression levels were calculated and are presented as the mean \pm SD. Statistical significance was determined by Student's t-test [statistical difference was indicated as $\mathrm{P}<0.05$, when compared with (a) the control group]. Cyt $c$, cytochrome $c$; Cas-3, caspase-3; Cas-8, caspase-8; Cas-9, caspase-9; GC, gastric cancer; NS, normal saline; ACBP, anticancer bioactive peptide; L-OHP, oxaliplatin; A+L, combination of anticancer bioactive peptide and oxaliplatin; SD, standard deviation.

cytochrome $c$, caspase-3, -8 , and -9 was higher in the GC cells. Protein expression was examined via conventional semi-quantitative score methods (Fig. 8A). Cytochrome $c$, caspase $-3,-8$, and -9 were positively expressed in the GC cells. The immunohistochemical scores for cytochrome $c$, caspase- $3,-8$, and -9 protein expression changed from 12 to 17,15 to 18,5 to 10 , and 3 to 5 , respectively in the drug-treated (ACBP to $\mathrm{A}+\mathrm{L})$ tumor tissues, indicating that $(\mathrm{A}+\mathrm{L})$-treated cells displayed statistically significant $(\mathrm{P}<0.05)$ expression compared to scores $(10,12,1$, and 2 , respectively) from the matched control. Quantitative analysis indicated that the levels of caspase- 8 in the GC tissues treated with L-OHP were significantly higher than in the NS control $(\mathrm{P}<0.05)$.

Gene expression of cytochrome c, caspase-3, -8, and -9 in $G C$ tissue. RT-PCR and electrophoresis were used to analyze the expression of cytochrome $c$, caspase-3, -8 , and -9 in $\mathrm{GC}$ tissues (Fig. 8B and C). Gene expression of cytochrome $c$, caspase-3, -8 , and -9 was increased following the A+L, L-OHP, and ACBP treatments relative to the NS control, although the differences were not significant $(\mathrm{P}>0.05)$, except for that between the $\mathrm{A}+\mathrm{L}$ and NS treatments $(\mathrm{P}<0.05)$.

\section{Discussion}

ACBPs are a leading prospect for the treatment of many diseases, as they were found to inhibit the growth of Dutch GCMGC-803 and BGC-823 cells and gallbladder carcinoma GBC-SD cells. Daily ACBP in combination with continuous cisplatin improves the efficacy of cisplatin, reduces its use, and decreases the toxicity of chemotherapy drugs $(26,27)$. In the present study, ACBP (normal and/or induced) and L-OHP treatment of MKN-45 GC cells showed significant inhibition of cell proliferation in a dose-dependent manner after $24 \mathrm{~h}$. $\mathrm{A}+\mathrm{L}$ was more effective than either drug alone at inhibiting cell growth $(\mathrm{P}<0.05)$. The growth IR was better in the $\mathrm{A}+\mathrm{L}$ group compared to the L-OHP alone group; the difference was significant $(\mathrm{P}<0.05)$. For each experimental group compared with the control group, the cell numbers were reduced, the cell morphology ranged in size, and the cells displayed 
poor adherence, cell shrinkage, and cell lysis. The number of adherent cells was significantly reduced in the $30 \mu \mathrm{g} / \mathrm{ml}$ $\mathrm{ACBP}+20 \mu \mathrm{g} / \mathrm{ml} \mathrm{L}-\mathrm{OHP}$ combination drug-treated cells. Cell-free zones, suspension cells and karyopyknosis were visible, although the cell contours were not obvious. Therefore, short-term application of ACBP and L-OHP inhibited human GC cell growth. A+L increased the utility and reduced the toxicity of L-OHP.

We also investigated the short-term intermittent application of induced ACBP with L-OHP in human gastric carcinoma xenograft tumors. MKN-45 GC cells were subcutaneously inoculated in nude mice for xenograft tumor model preparation. We demonstrated that discontinuous short-term injection of ACBP improved the food intake, activity, and body weight of the nude mice and inhibited tumor growth compared with the control mice, although free ACBP showed no significant differences. The spleen coefficient significantly decreased with ACBP treatment relative to NS $(\mathrm{P}<0.05)$, and decreased liver and spleen tissue injury indicated an improved quality of life for the tumor-bearing nude mice. Furthermore, intraperitoneal injection of $\mathrm{A}+\mathrm{L}$ increased the feeding, activity, and body weight of nude mice and decreased liver and spleen damage and coefficients compared to treatment with free L-OHP $(\mathrm{P}<0.05)$. The results indicate that $\mathrm{A}+\mathrm{L}$ mitigates $\mathrm{L}-\mathrm{OHP}$ toxicity and improves the quality of life of tumor-bearing nude mice.

Previous studies of the mechanisms of tumor occurrence suggest that malignant tumors occur and develop not only from accelerated proliferation and decreased apoptosis but also from the relationships between inhibition, abnormal proliferation, and apoptotic regulation. Some scholars believe that the main driver of malignant tumor development is inhibition of normal cell apoptosis. Apoptosis is a cellular suicide program, and inducing apoptosis is a key tactic for eliminating cancer cells without stimulating an inflammatory reaction. Several conventional drugs believed to induce cell apoptosis via activation of these elements are currently used in anticancer chemotherapy (28). Therefore, an increasing understanding of the inhibitory mechanisms of cell apoptosis is providing new insights into tumor development.

Current research shows that apoptosis is closely related to the cell cycle (29), which has become a new target for cancer therapy. Many anticancer drugs function primarily to induce apoptosis in cancer cells and prevent tumor development $(30,31)$. In many cases, extensive DNA damage leads to activation of cell cycle check points and results in cell cycle arrest and apoptosis (32). Previous studies have shown that ACBP promoted cell proliferation in GC cells and inhibited MGC-803 cancer cells (17) and L-OHP-resistant human colon cancer cell lines with increasing dose of L-OHP in culture (33). In this study, we found that $\mathrm{A}+\mathrm{L}$ induced apoptosis in MKN-45 cells, which was revealed by the PI assay. When the cells were treated with NS, L-OHP, ACBP and A+L for $48 \mathrm{~h}$, the average proportion of PI staining-positive cells was significantly increased from $3.24 \%$ in the control to $10.75,21.56$ and $23.15 \%$ in the L-OHP, ACBP and A+L groups, respectively. We also evaluated the effect of NS, L-OHP, ACBP and A+L on cell cycle phase distribution using flow cytometry. It was observed that ACBP and L-OHP induced cell cycle arrest in the $\mathrm{S}$ and $\mathrm{G} 2 / \mathrm{M}$ phase, respectively.
In recent years, caspases have been used to determine the apoptotic state, as they play a critical role in the apoptotic molecular mechanism. Currently, most in-depth studies of apoptosis in mammalian cells focus on death receptor- and mitochondrial-mediated apoptosis. Mitochondrial-mediated apoptosis involves the release of cytochrome $c$ from the mitochondria. It combines with Apaf-1 and, in the presence of dATP or ATP, oligomerically activates caspase-9, which starts the caspase downstream cascade and promotes apoptosis (34). In these two apoptotic pathways, activation of the caspase cascade is critical; caspase-3 activation, which is downstream, is the central link between the two apoptotic pathways. It has been shown that caspase-3 expression was significantly lower in gastric carcinoma than in adjacent normal gastric mucosa. This suggests that the decrease in caspase-3 expression in GC cells, which inhibits the cells from undergoing apoptosis, may be involved in the formation of gastric carcinomas. ACBPs have been confirmed to promote p16, p21, p27, caspase-8, and Bax mRNA expression (17,26). These results suggest that ACBPs could inhibit tumor growth through the induction of the apoptosis-related genes caspase-3, -8 and -9. Existing research has demonstrated that expression of caspase-3, -8 , and -9 in GC tissue is obviously lower than in adjacent normal gastric mucosa tissue, suggesting that inhibition of apoptosis may be key to GC progression (35). In contrast, expression of cytochrome $c$, a known pro-apoptotic factor, decreased with decreasing $\mathrm{GC}$ tissue differentiation.

We found that $\mathrm{A}+\mathrm{L}$ significantly decreased tumor weight $(\mathrm{P}<0.05)$, whereas there was no significant difference between the L-OHP group ( $\mathrm{P}>0.05)$ and the NS group. The gene expression results indicated that short-term intraperitoneal injection of $\mathrm{A}+\mathrm{L}$ could increase the antitumor effect of L-OHP.

Overall, ACBP inhibited tumor growth via a short-term application and improved the quality of life of tumor-bearing nude mice after MKN-45 cell transplantation compared to control. Short-term application of A+L also inhibited tumor growth and improved the quality of life of nude mice after MKN-45 cell transplantation compared to free L-OHP. In addition, $\mathrm{A}+\mathrm{L}$ increased the utility of L-OHP and reduced the toxicity of chemotherapeutics. These results support a new approach for exploring the comprehensive treatment of GC.

In summary, we demonstrated novel anticancer activity for peptides (normal or induced ACBP) and showed that they could be used in a strategy to reduce the toxicity of L-OHP. Our results indicated that combination therapy with induced ACBP and L-OHP inhibited cancer cell growth at high concentrations $(30 \mu \mathrm{g} / \mathrm{ml}$ ACBP $+20 \mu \mathrm{g} / \mathrm{ml} \mathrm{L-OHP})$, suggesting that at these concentrations ACBP plays a role in MKN-45 cells and also lead to apoptosis. In addition, our findings highlight the importance of L-OHP in the anticancer activity of the peptide. By decreasing the toxicity of L-OHP, we increased its antitumor activity, providing useful information for the design of conjugate anticancer peptides and chemotherapeutics with selective target properties. We validated that the combination of induced ACBP and L-OHP was useful in GC therapy in a human gastric carcinoma xenograft tumor model. We observed that the expression of caspase-3, -8, -9 and cytochrome $c$ was higher in cells treated with induced ACBP, L-OHP and A+L than in the NS control. Short-term intermittent treatment with ACBP alone has a certain role in inhibiting tumor growth, 
while short-term intermittent $\mathrm{A}+\mathrm{L}$ treatment mainly increases the L-OHP sensitizing effect, reduces the side-effects associated with chemotherapy, and improves the quality of life of nude mice. This study provides not only further evidence of the remarkable antitumor effects of ACBP (normal or induced) but also a new strategy of combination therapy for clinical investigation.

\section{Acknowledgements}

We are grateful to all participants in this study. This study was supported by a grant from the National Natural Science Foundation of China (\#81260058 and \#81450047).

\section{References}

1. Kassam Z, Mackay H, Buckley CA, Fung S, Pintile M, Kim J and Ringash J: Evaluating the impact on quality of life of chemoradiation in gastric cancer. Curr Oncol 17: 77-84, 2010.

2. Chen XZ, Zhang WH and Hu JK: A difficulty in improving population survival outcome of gastric cancer in mainland China: Low proportion of early diseases. Med Oncol 31: 315, 2014.

3. Ye L, Zhang ZY, Du WD, Schneider ME, Qiu Y, Zhou Y, Zhou FS, Zuo XB, Chen G, Ma XL, et al: Genetic analysis of ADIPOQ variants and gastric cancer risk: A hospital-based case-control study in China. Med Oncol 30: 658, 2013.

4. Siegel R, Ma J, Zou Z and Jemal A: Cancer statistics, 2014. CA Cancer J Clin 64: 9-29, 2014.

5. Fock KM: Review article: The epidemiology and prevention of gastric cancer. Aliment Pharmacol Ther 40: 250-260, 2014.

6. Soulié P, Bensmaïne A, Garrino C, Chollet P, Brain E, Fereres M, Jasmin C, Musset M, Misset JL and Cvitkovic E: Oxaliplatin/cisplatin (L-OHP/CDDP) combination in heavily pretreated ovarian cancer. Eur J Cancer 33: 1400-1406, 1997.

7. Dong HL and Chen M: GEM combination 5-Fu/L-OHP treatment of advanced pancreatic cancer, effect observation of 47 cases. Mod Prev Med 35: 3872-3873, 2008.

8. Zhang C, Ren Z and Li C: Recent effect of combination chemotherapy of hydroxycamptothecin and 5-FU, MMC for advanced pancreatic cancer. Guangzhou Med J 34: 38-39, 2003.

9. Rebucci M and Michiels C: Molecular aspects of cancer cell resistance to chemotherapy. Biochem Pharmacol 85: 1219-1226, 2013.

10. Cervantes A, Roselló S, Roda D and Rodríguez-Braun E: The treatment of advanced gastric cancer: Current strategies and future perspectives. Ann Oncol 19 (Suppl 5): v103-v107, 2008.

11. Yoong J, Michael $M$ and Leong T: Targeted therapies for gastric cancer: Current status. Drugs 71: 1367-1384, 2011.

12. Mathé G, Kidani Y, Noji M, Maral R, Bourut C and Chenu E: Antitumor activity of 1-OHP in mice. Cancer Lett 27: 135-143, 1985.

13. Degardin M, Cappelaere P, Krakowski I, Fargeot P, Cupissol D and Brienza S: Phase II trial of oxaliplatin (L-OHP) in advanced, recurrent and/or metastatic squamous cell carcinoma of the head and neck. Eur J Cancer B Oral Oncol 32B: 278-279, 1996.

14. Fiteni F, Nguyen T, Vernerey D, Paillard MJ, Kim S, Demarchi M, Fein F, Borg C, Bonnetain F and Pivot X: Cisplatin/gemcitabine or oxaliplatin/gemcitabine in the treatment of advanced biliary tract cancer: A systematic review. Cancer Med 3: 1502-1511, 2014.

15. Zhang C, Jia S and Su X: Effect of anticancer bioactive peptide on the gene expression of human gastric cancer BGC-823 cells. J Clin Oncol 37: 1021-1023, 2010.

16. Wen ZH and Su XL: The effect of anti-cancer bioactive peptide on the expression of p53 and Bcl-2 of tumor tissues of experimental nude mice. Med Rev 17: 1557-1559, 2011.
17. Su X, Dong C, Zhang J, Su L, Wang X, Cui H and Chen Z: Combination therapy of anti-cancer bioactive peptide with Cisplatin decreases chemotherapy dosing and toxicity to improve the quality of life in xenograft nude mice bearing human gastric cancer. Cell Biosci 4: 7, 2014.

18. Sui CG, Meng FD, Li Y and Jiang YH: Antiproliferative activity of rosamultic acid is associated with induction of apoptosis, cell cycle arrest, inhibition of cell migration and caspase activation in human gastric cancer (SGC-7901) cells. Phytomedicine 22: 796-806, 2015.

19. Livak KJ and Schmittgen TD: Analysis of relative gene expression data using real-time quantitative PCR and the 2(- $\Delta \Delta \mathrm{C}(\mathrm{T}))$ method. Methods 25: 402-408, 2001.

20. Tu K, Zheng X, Zhou Z, Li C, Zhang J, Gao J, Yao Y and Liu Q: Recombinant human adenovirus-p53 injection induced apoptosis in hepatocellular carcinoma cell lines mediated by p53-Fbxw7 pathway, which controls c-Myc and cyclin E. PLoS One 8: e68574, 2013

21. Yao HJ, Zhang YG, Sun L and Liu Y: The effect of hyaluronic acid functionalized carbon nanotubes loaded with salinomycin on gastric cancer stem cells. Biomaterials 35: 9208-9223, 2014.

22. Wang J, Chen X, Su L, Li P, Cai Q, Liu B, Wu W and Zhu Z: MicroRNA-126 inhibits cell proliferation in gastric cancer by targeting LAT-1. Biomed Pharmacother 72: 66-73, 2015.

23. Tu K, Zheng X, Zan X, Han S, Yao Y and Liu Q: Evaluation of Fbxw7 expression and its correlation with the expression of c-Myc, cyclin E and p53 in human hepatocellular carcinoma. Hepatol Res 42: 904-910, 2012.

24. Yin T, Lu L, Xiong Z, Wei S and Cui D: ATPase inhibitory factor 1 is a prognostic marker and contributes to proliferation and invasion of human gastric cancer cells. Biomed Pharmacother 70: 90-96, 2015.

25. Stacul F, Bertolotto M, De Gobbis F, Calderan L, Cioffi V, Romano A, Zanconati F and Cova MA: US, colour-Doppler US and fine-needle aspiration biopsy in the diagnosis of thyroid nodules. Radiol Med (Torino) 112: 751-762, 2007.

26. Yu L, Yang L, An W and Su X: Anticancer bioactive peptide-3 inhibits human gastric cancer growth by suppressing gastric cancer stem cells. J Cell Biochem 115: 697-711, 2014.

27. Su L, Xu G, Shen J, Tuo Y, Zhang X, Jia S, Chen Z and Su X: Anticancer bioactive peptide suppresses human gastric cancer growth through modulation of apoptosis and the cell cycle. Oncol Rep 23: 3-9, 2010.

28. Kundu T, Dey S, Roy M, Siddiqi M and Bhattacharya RK: Induction of apoptosis in human leukemia cells by black tea and its polyphenol theaflavin. Cancer Lett 230: 111-121, 2005.

29. Alshatwi AA, Athinarayanan J and Periasamy VS: Green synthesis of bimetallic Au@Pt nanostructures and their application for proliferation inhibition and apoptosis induction in human cervical cancer cell. J Mater Sci Mater Med 26: 148, 2015.

30. Khoo BY, Chua SL and Balaram P: Apoptotic effects of chrysin in human cancer cell lines. Int J Mol Sci 11: 2188-2199, 2010.

31. Li W, Wang J, Jiang HR, Xu XL, Zhang J, Liu ML and Zhai LY: Combined effects of cyclooxygenase- 1 and cyclooxygenase-2 selective inhibitors on ovarian carcinoma in vivo. Int $\mathbf{J}$ Mol Sci 12: 668-681, 2011.

32. Pietenpol JA and Stewart ZA: Cell cycle checkpoint signaling: Cell cycle arrest versus apoptosis. Toxicology 181-182: 475-481, 2002.

33. Xiang Z, Kang QJ and Xiang X: Gene and protein expression in the oxaliplatin-resistant HT29/L-OHP human colon cancer cell line. Genet Mol Res 14: 11013-11022, 2015.

34. Reubold TF and Eschenburg S: A molecular view on signal transduction by the apoptosome. Cell Signal 24: 1420-1425, 2012.

35. Huang L, Zhang T, Li S, Duan J, Ye F, Li H, She Z, Gao G and Yang X: Anthraquinone G503 induces apoptosis in gastric cancer cells through the mitochondrial pathway. PLoS One 9: e108286, 2014. 